$11-15-2004$

\title{
Azaadamantane Benzamide 5-HT4 Agonists: Gastrointestinal Prokinetic SC-54750
}

\author{
Daniel Becker \\ Loyola University Chicago, dbecke3@luc.edu \\ Daniel L. Flynn \\ Robert L. Shone \\ Gary Gullikson
}

Follow this and additional works at: https://ecommons.luc.edu/chemistry_facpubs

Part of the Chemistry Commons

Author Manuscript

This is a pre-publication author manuscript of the final, published article.

\section{Recommended Citation}

Becker, Daniel; Flynn, Daniel L.; Shone, Robert L.; and Gullikson, Gary. Azaadamantane Benzamide 5-HT4 Agonists: Gastrointestinal Prokinetic SC-54750. Bioorganic \& Medicinal Chemistry Letters, 14, 22: , 2004. Retrieved from Loyola eCommons, Chemistry: Faculty Publications and Other Works, http://dx.doi.org/ 10.1016/j.bmcl.2004.09.005

This Article is brought to you for free and open access by the Faculty Publications and Other Works by Department at Loyola eCommons. It has been accepted for inclusion in Chemistry: Faculty Publications and Other Works by an authorized administrator of Loyola eCommons. For more information, please contact ecommons@luc.edu. cc) (i) $\Theta$

This work is licensed under a Creative Commons Attribution-Noncommercial-No Derivative Works 3.0 License. (c) 2004 Elsevier 


\section{Azaadamantane Benzamide 5-HT4 Agonists: Gastrointestinal Prokinetic SC-54750}

Daniel P. Becker*, Daniel L. Flynn, Robert L. Shone, and Gary Gullikson

Department of Medicinal Chemistry, Pfizer Research \& Development, 4901 Searle Parkway, Skokie, IL 60077

Aazaadamantanone $\mathbf{1}$ was converted to a series of aminoazaadamantane benzamides $\mathbf{9 a - d}$ which were profiled for serotonin receptor activity. Aminomethylazaadamantane SC-54750 is a potent 5- $\mathrm{HT}_{4}$ agonist and 5-HT 3 antagonist with in vivo efficacy in gastroparesis models and also inhibits cisplatin-induced emesis.

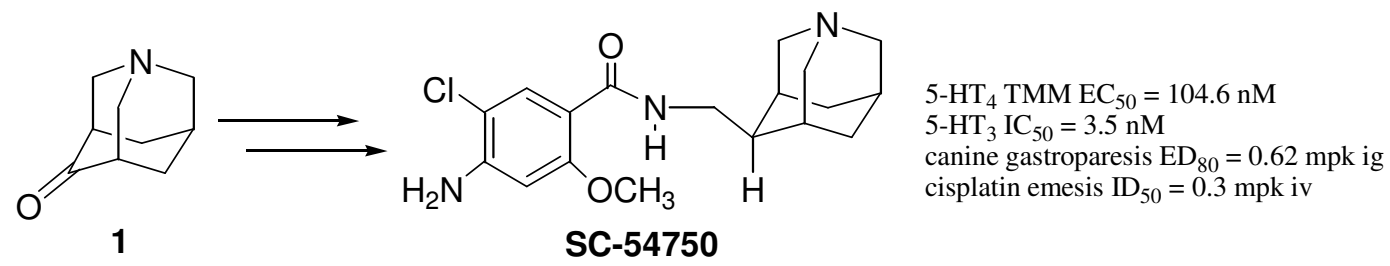




\title{
Azaadamantane Benzamide 5-HT4 Agonists: Gastrointestinal Prokinetic SC-54750
}

\author{
Daniel P. Becker*, Daniel L. Flynn ${ }^{\S}$, Robert L. Shone ${ }^{\ddagger}$, and Gary Gullikson \\ Departments of Medicinal Chemistry and Pharmacology, Pfizer Research \& Development, 4901 \\ Searle Parkway, Skokie, IL 60077 \\ *Corresponding author at present address: Department of Chemistry, Loyola University, 6525 North Sheridan Road, \\ Chicago, IL 60626, dbecke3@luc.edu \\ ${ }^{\S}$ Current address: Deciphera Pharmaceuticals Inc., 1505 Wakarusa Drive, Lawrence, KS 66047 USA \\ ${ }^{\ddagger}$ Current address: 1441 E. Joan Dr., Palatine, IL 60074
}

\begin{abstract}
Azaadamantanone 1 was converted to a series of aminoazaadamantane benzamides 9a-d which were profiled for serotonin receptor activity. Aminomethylazaadamantane SC$\mathbf{5 4 7 5 0}$ is a potent $5-\mathrm{HT}_{4}$ agonist and $5-\mathrm{HT}_{3}$ antagonist with in vivo efficacy in gastroparesis models and also inhibits cisplatin-induced emesis.
\end{abstract}

Serotonin (5-hydroxytryptamine, 5-HT) functions as both a hormone and a neurotransmitter, controlling a host of central and peripheral effects via a number of receptors. ${ }^{1}$ The $5-\mathrm{HT}_{4}$ receptor was discovered by $\mathrm{Clark}^{2}$ and Bockaert ${ }^{3}$ in the brain and gut, respectively, and is expressed in a wide variety of tissues including brain, heart, bladder, gut and kidney. ${ }^{4,5}$ Initial demonstration that renzapride and cisapride could enhance contractile activity at neuronal 5- $\mathrm{HT}_{4}$ receptors in the guinea pig ileum was made by Craig and Clarke. ${ }^{6}$ It was later demonstrated that $5-\mathrm{HT}_{4}$ receptors mediate the relaxation of smooth muscle of the inner muscularis mucosae of rat esophagus $^{7}$ and also the cholinergic stimulation of the ascending colon of the guinea pig. ${ }^{8}$ The 5-HT 4 partial agonist tegaserod (SDZ HTF 919) was approved in 2002 for the treatment of constipation-predominant irritable bowel syndrome (IBS). ${ }^{9}$ Tegaserod showed a clear effect on the total colonic transit time in healthy subjects, and a significant improvement in patients with constipation-predominant IBS in a phase III trial. ${ }^{10}$ Cisapride (PrepulsidTM) had been marketed for motility disorders ${ }^{11}$ but was withdrawn due to potent hERG block and QT prolongation. ${ }^{12}$ An excellent review of the $5-\mathrm{HT}_{4}$ receptor and key ligands was recently published. ${ }^{13}$

We have investigated a number of conformationally-constrained tertiary amine derivatives as serotonin 5- $\mathrm{HT}_{4}$ agonist and antagonists, and as 5- $\mathrm{HT}_{3}$ antagonists. ${ }^{14}$ We previously reported the $5-\mathrm{HT}_{4}$ activity of pyrrolizidine $\mathbf{S C - 5 3 1 1 6},{ }^{15}$ the first selective $5-\mathrm{HT}_{4}$ agonist, and SC-53606, a selective $5-\mathrm{HT}_{4}$ antagonist. ${ }^{16}$ We have also reported the blended $5-\mathrm{HT}_{3} / 5-\mathrm{HT}_{4}$ activity of azanoradamantane SC-52491 ${ }^{17}$, which is a mixed 5- $\mathrm{HT}_{4}$ agonist/5-HT 3 antagonist, and of a series of meso-azanoradamantanes. ${ }^{18}$ Azaadamantanes are theoretically interesting molecules ${ }^{19}$ with many potential uses ${ }^{20}$ and have the advantage that they lack chirality. Herein we detail our investigation of aminoazaadamantane benzamides and disclose the aminomethylazaadamantane clinical candidate $\mathbf{S C - 5 4 7 5 0}$, a selective $5-\mathrm{HT}_{4}$ agonist with excellent in vivo pharmacology demonstrating utility as a gastrointestinal prokinetic agent. 
<smiles>CCCCCCNC(=N)N/N=C/c1c[nH]c2ccc(OC)cc12</smiles><smiles>COc1cc(N)c(Cl)cc1C(=O)NC[C@@H]1CCN2CCC[C@H]12</smiles>

SC-53116<smiles>COc1cc(N)c(Cl)cc1C(=O)NC1C2CC3CN(C2)CC31</smiles>

SC-52491

We previously reported the synthesis of the individual syn and anti aminoazaadamantanes $\mathbf{2}$ and 3 via 1-azatricyclo[3.3.1.1 ${ }^{3,7}$ ]decan-4-one $\mathbf{1}$ (Scheme 1). ${ }^{21}$ Homologation of $\mathbf{1}$ was accomplished utilizing van Leusen's reductive alkylation ${ }^{22}$ of $\mathbf{1}$ with tosylmethyl isocyanide (TosMIC) to give the nitriles 4 and $\mathbf{5}$ (Scheme 2), which were separated by chromatography on silica gel eluting with $\mathrm{MeOH}\left(\mathrm{NH}_{3}\right) / \mathrm{CHCl}_{3}$. Reduction of the nitriles independently with lithium aluminum hydride gave the distillable amines 6 and 7, which suffered $\leq 2 \%$ epimerization in the reduction procedure. Benzamide coupling of the aminoazaadamantanes with 4-amino-5-chloro-2-methoxy benzoic acod $\mathbf{8}$ utilizing carbonyldiimidazole (CDI) as the coupling reagent gave the requisite aminoazaadamantane benzamides which were treated with hydrogen chloride to afford the crystalline monohydrochloride salts 9a-d (Scheme 3).

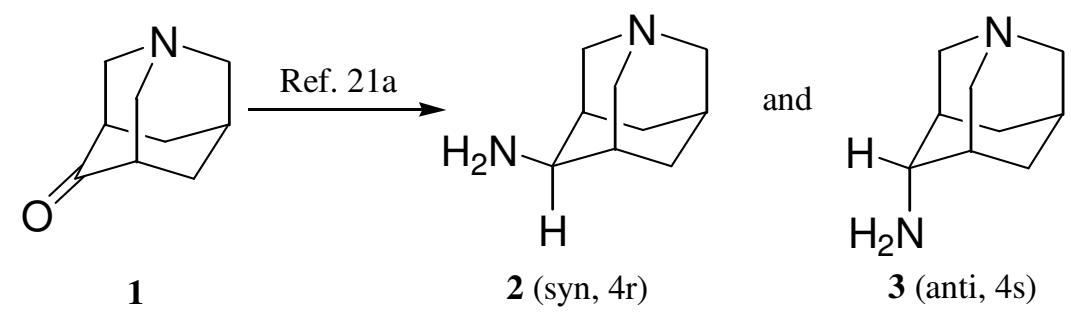

Scheme 1. Preparation of epimeric aminoazaadamantanes 2 and 3. 


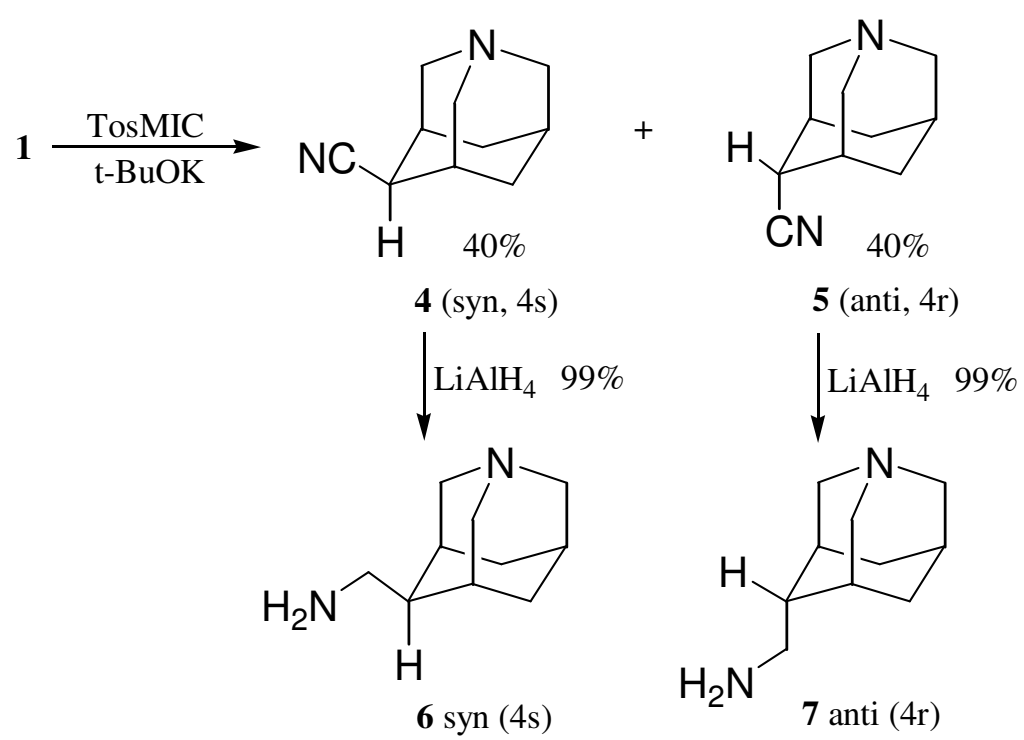

Scheme 2. Synthesis of epimeric aminomethylazaadamantanes 6 and 7.

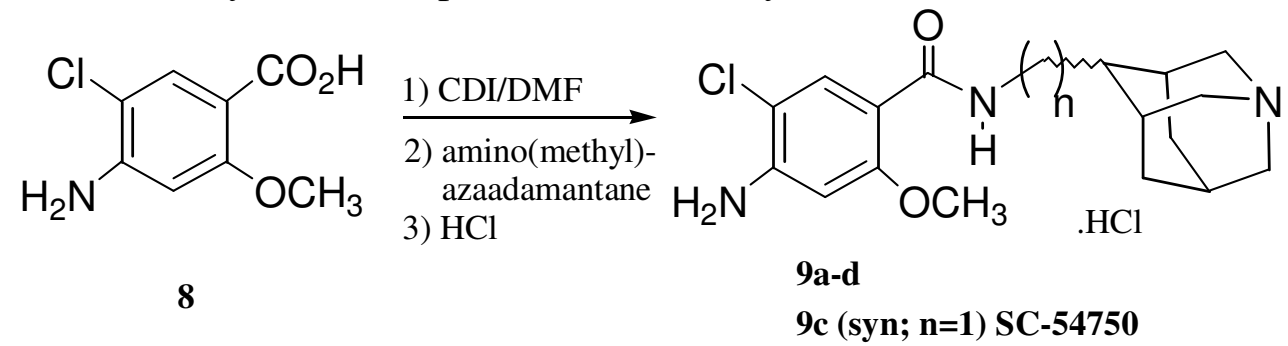

Scheme 3. Coupling procedure to afford aminoazaadamantane benzamides 9a-d.

As seen in Table 1, anti-aminoazaadamantane $\mathbf{9 b}$ is twice as potent as the corresponding synisomer 9a in 5- $\mathrm{HT}_{4}$ agonism in the rat tunica muscularis mucosae (TMM) assay, ${ }^{23}$ and the antiisomer is an order of magnitude more potent in $5-\mathrm{HT}_{4}$ receptor binding ${ }^{24}(\mathrm{Ki}=57 \mathrm{nM}$ vs. $>500$ $\mathrm{nM})$. Anti-aminoazaadamantane $\mathbf{9 b}$ is also substantially (37X) more potent than the syn-isomer in 5- $\mathrm{HT}_{3}$ binding. ${ }^{25}$ This greater potency for the $5-\mathrm{HT}_{3}$ receptor is also revealed in the BezoldJarisch reflex ${ }^{26}$ in mice, where $9 \mathbf{b}$ affords $>50 \%$ inhibition down to $0.03 \mathrm{mpk}$ ip, whereas $9 \mathbf{a}$ is inactive at $3 \mathrm{mpk}$. With the homologated aminomethylazaadamantanes, it is the syn-isomer that is more potent at both receptors. Syn-isomer $\mathbf{9 c}(\mathbf{S C - 5 4 7 5 0 )}$ is $5 \mathrm{X}$ more potent than anti-isomer 9d as an agonist at the $5-\mathrm{HT}_{4}$ receptor in the TMM assay $(73.6 \mathrm{nM}$ vs. $545 \mathrm{nM})$ and is $5 \mathrm{X}$ more potent in binding at the $5-\mathrm{HT}_{3}$ receptor $(\mathrm{Ki}=25.4 \mathrm{nM}$ vs. $143.7 \mathrm{nM})$. This differential in $5-\mathrm{HT}_{3}$ potency is reflected in the greater potency of inhibition of the $5-\mathrm{HT}_{3}$ receptor by $\mathbf{S C - 5 4 7 5 0}$ in the von Bezold-Jarisch reflex assay, with $\mathbf{9 c}$ affording $>50 \%$ inhibition down to $0.1 \mathrm{mpk}$ versus $\mathbf{9 d}$, which is inactive at $1 \mathrm{mpk}$.

Aminomethylazaadamantane $\mathbf{S C - 5 4 7 5 0}$ is highly selective versus other monoamine receptors, ${ }^{27}$ as are the other azaadamantane derivatives, as summarized in Table 2, with no affinity detected $\left(\mathrm{IC}_{50}>10,000 \mathrm{nM}\right)$ for serotonin $5-\mathrm{HT}_{1}$ or $5-\mathrm{HT}_{2}$ receptors, dopamine $\mathrm{D}_{1}$ or $\mathrm{D}_{2}$ receptors, $\alpha_{1}$ or $\alpha_{2}$ adrenergic receptors, or $\beta$-adrenergic receptors. SC-54750 is quite similar to SC-52491 in potency for both $5-\mathrm{HT}_{4}$ and $5-\mathrm{HT}_{3}$ receptors and possesses exquisite selectivity versus other monoamine receptors. Cisapride, in contrast, binds to $\mathrm{D}_{2}$ and $\alpha_{1}$ receptors, and is exceptionally potent for the $5-\mathrm{HT}_{2}$ receptor $\left(\mathrm{IC}_{50}=6.1 \mathrm{nM}\right)$. 
Table 1. In vitro serotonergic activity of aminoazaadamantane benzamides 9 a-d<smiles>COc1cc(N)c(Cl)cc1C(=O)NCCC1C2CC3CC1CN(C3)C2</smiles><smiles>COc1cc(N)c(Cl)cc1C(=O)NC(=O)C1CN2CC3CC1CC32</smiles>

9a $(\mathrm{n}=0)$

9b $(\mathrm{n}=0)$

$9 c(n=1 ;$ SC-54750)

\begin{tabular}{|c|c|c|c|c|c|}
\hline $\begin{array}{l}\text { Entry } \\
\text { (stereo) }\end{array}$ & $\mathrm{n}$ & $\begin{array}{l}\text { 5- } \mathrm{HT}_{4} \text { Binding } \\
\mathrm{Ki}, \mathrm{nM}(\mathrm{SEM})\end{array}$ & $\begin{array}{l}\text { 5- } \mathrm{HT}_{4} \text { agonism } \\
\text { in rat } \mathrm{TMM} \\
\text { EC50 }(\mathrm{nM})\end{array}$ & $\begin{array}{l}\text { 5- } \mathrm{HT}_{3} \\
\text { Binding } \\
\mathrm{Ki}(\mathrm{nM})\end{array}$ & $\begin{array}{l}\text { Bezold-Jarisch Reflex, } \\
\text { 5- } \mathrm{HT}_{3} \text { antagonism, } \\
\% \text { inhib at dose (mpk ip) }\end{array}$ \\
\hline $\begin{array}{l}9 \mathbf{a} \\
(\text { syn })\end{array}$ & 0 & $>500$ & 538 & 336 & $\begin{array}{l}85 \% \text { at } 10 \\
0 \% \text { at } 3\end{array}$ \\
\hline $\begin{array}{l}\text { 9b } \\
\text { (anti) }\end{array}$ & 0 & 57 & 262 & 9 & $\begin{array}{l}86 \% \text { at } 10 \\
81 \% \text { at } 3 \\
75 \% \text { at } 1 \\
70 \% \text { at } 0.3 \\
64 \% \text { at } 0.1 \\
61 \% \text { at } 0.03\end{array}$ \\
\hline $\begin{array}{l}\text { 9c } \\
(\text { syn) } \\
\text { SC-54750 }\end{array}$ & 1 & 51 & 73.6 & 25.4 & $\begin{array}{l}88 \% \text { at } 10 \\
82 \% \text { at } 8 \\
82 \% \text { at } 1 \\
75 \% \text { at } 0.3 \\
60 \% \text { at } 0.1 \\
0 \% \text { at } 0.03\end{array}$ \\
\hline $\begin{array}{l}\text { 9d } \\
\text { (anti) }\end{array}$ & 1 & ND & 545 & 143.7 & $\begin{array}{l}85 \% \text { at } 10 \\
82 \% \text { at } 3 \\
0 \% \text { at } 1 \\
\end{array}$ \\
\hline
\end{tabular}


Table 2. Receptor profiling of azaadamantane benzamides 9a-d and cisapride: ED50 [5-HT 4 or $\mathrm{IC}_{50}$ [all others], nM

\begin{tabular}{|l|l|l|l|l|l|l|l|l|l|}
\hline Entry & $\mathbf{5 - H T}_{\mathbf{4}}$ & $\mathbf{5 - H T}_{\mathbf{3}}$ & $\mathbf{5 - H T}_{\mathbf{1}}$ & $\mathbf{5 - H T}_{\mathbf{2}}$ & $\mathbf{D}_{\mathbf{1}}$ & $\mathbf{D}_{\mathbf{2}}$ & $\boldsymbol{\alpha}_{\mathbf{1}}$ & $\boldsymbol{\alpha}_{\mathbf{2}}$ & $\boldsymbol{\beta}$ \\
\hline 9a & 538 & 672 & $>10 \mathrm{~K}$ & 1800 & $>10 \mathrm{~K}$ & $>10 \mathrm{~K}$ & $>10 \mathrm{~K}$ & 6400 & $>10 \mathrm{~K}$ \\
\hline 9b & 262 & 18 & $>10 \mathrm{~K}$ & $>10 \mathrm{~K}$ & $>10 \mathrm{~K}$ & $>10 \mathrm{~K}$ & $>10 \mathrm{~K}$ & $>10 \mathrm{~K}$ & $>10 \mathrm{~K}$ \\
\hline 9c SC-54750 & 73.6 & 3.5 & $>10 \mathrm{~K}$ & $>10 \mathrm{~K}$ & $>10 \mathrm{~K}$ & $>10 \mathrm{~K}$ & $>10 \mathrm{~K}$ & $>10 \mathrm{~K}$ & $>10 \mathrm{~K}$ \\
\hline 9d & 545 & 11 & $\mathrm{ND}$ & $\mathrm{ND}$ & $\mathrm{ND}$ & $>10 \mathrm{~K}$ & $\mathrm{ND}$ & $\mathrm{ND}$ & ND \\
\hline SC-52491 & 51.3 & 2.3 & $>10 \mathrm{~K}$ & $>10 \mathrm{~K}$ & $>10 \mathrm{~K}$ & $>10 \mathrm{~K}$ & $>10 \mathrm{~K}$ & $>10 \mathrm{~K}$ & $>10 \mathrm{~K}$ \\
\hline Cisapride & 54.7 & 134 & $>10 \mathrm{~K}$ & 6.1 & 1700 & 227 & 30 & 4500 & $>10 \mathrm{~K}$ \\
\hline
\end{tabular}


SC-54750 was selected for further study and was found to be a potent stimulator of gastric emptying in rats, with comparable activity that is observed for oral dosing when given at $3 \mathrm{X}$ the iv dose. SC-54750 is a potent stimulator of gastric contractile activity in fasted dogs that were surgically implanted with strain gauges. ${ }^{28}$ SC-54750 is comparable to cisapride in eliciting antral contractions, with intestinal myoelectric spike burst (contractile) activity that is stimulated in the same dose range.

The dosages responsible for eliciting gastric antral contractile responses in dogs corresponded well to the gastric emptying profiles. In a canine gastroparesis model of $5-\mathrm{HT}_{4}$ agonism $^{29} \mathbf{S C}$ 54750 is potent and efficacious in restoring normal motility, exhibiting an $\mathrm{EC}_{50}$ of $0.03 \mathrm{mg} / \mathrm{kg}$ iv and an $\mathrm{ED}_{80}$ of $0.62 \mathrm{mg} / \mathrm{kg}$, ig. The $5-\mathrm{HT}_{3}$ antagonism of $\mathbf{S C - 5 4 7 5 0}$ gives rise to effective inhibition of cisplatin-induced emesis in dogs, with an $\mathrm{ID}_{50}$ of $0.3 \mathrm{mg} / \mathrm{kg}$, iv. The compound was orally active in this model as well.

SC-54750 is an achiral gastrointestinal prokinetic benzamide which compares quite favorably with cisapride and SC-52491. SC-54750 is a potent 5- $\mathrm{HT}_{4}$ agonist and $5-\mathrm{HT}_{3}$ receptor antagonist with excellent selectivity. It is orally active in stimulating gastrointestinal motility and in blocking cisplatin-induced emesis.

\section{References and Notes}

1. Hoyer, D.; Clarke, D. E.; Fozard, J. R.; Hartig, P. R.; Martin, G. R..; Mylecharane, E. J.; Saxena, P. R.; Humphrey, P. P. Pharmacol. Rev. 1994, 46, 157-203.

2. Baxter, G. S.; Craig, D. A.; Clarke, D. E. Naunyn-Schmiedeberg's Arch. Pharmacol. 1991, $343,439$.

3. Dumuis, A.; Sebbon, M.; Bockaert, J. Naunyn-Schmiedeberg's Arch. Pharmacol. 1989, 340, 403.

4. Eglen, R. M.; Wong, E. H. F.; Dumuis, A.; Bockaert, J. Trends Pharmacol. Sci. 1995, 16, 391-397.

5. Hedge, S.; Eglen, R. FASEB J. 1996, 10, 1398-1407.

6. Craig, D. A.; Clarke, D. E. J. Pharmacol. Exp. Ther. 1990, 252, 1378-1386.

7. Ronde, P.; Ansanay, H.; Dumuis, A.; Miller, R.; Bockaert, J. J. Pharmacol. Exp. Ther. 1995, 272, 977-983.

8. Briejer, M. R.; Akkermans, L. M.; Meulemans, A. L.; Lefebvre, R. A.; Schuurkes, J. A. Naunyn Schmiedeberg's Arch Pharmacol. 1993, 347, 464-70.

9. (a) Camilleri, M. Aliment. Pharmacol. Ther. 2001, 15, 277-289. (b) Rivkin, A. Clin. Ther. 2003, 25, 1952-1974. (c) Drugs Future 2001, 26, 99-100.

10. Wagstaff, A. J.; Frampton, J. E.; Croom, K. F. Drugs 2003, 63, 1101-1120.

11. McGallum, R. W. Am. J. Gastroenterol. 1985, 80, 1008-1016.

12. (a) (12) Colatsky, T. J.; Argentieri, T. M. Drug. Dev. Res. 1994, 33, 235-249. (b) Ahmad, S. R.; Wolfe, S. M. Lancet 1995, 25, 508.

13. Langlois, M.; Fischmeister, R. J. Med. Chem. 2003, 46, 319.

14. Becker, D. P.; Goldstin, B.; Gullikson, G. W.; Loeffler, R.; Moormann, A.; Moummi, C.; Nosal, R.; Spangler, D.; Villamil, C. I.; Yang, D.-C.; Zabrowski, D. L.; Flynn, D. L. Pharmacochemistry Library, Vol. 24, Elsevier Science B. V.: Amsterdam, 1996, pp. 99-120. 
15. (a) Flynn, D. L.; Zabrowski, D. L.; Becker, D. P.; Nosal, R.; Villamil, C. I.; Gullikson, G. W.; Moummi, C. Yang, Dai-C. J. Med. Chem., 1992, 35, 1486. (b) Becker, D. P.; Flynn, D. L.; Villamil, C. I. Bioorg. Med. Chem. Lett. 2004 14, 3073-3075.

16. Yang, D. C.; Goldstin, B.; Moormann, A. E.; Flynn, D. L.; Gullikson, G. W. J. Pharmacol. Exp. Ther. 1993, 266, 1339- 1347.

17. (a) Flynn, D. L.; Becker, D. P.; Spangler, D. P.; Nosal, R.; Gullikson, G. W.; Moummi, C.; Yang, D.-C. Bioorg. Med. Chem. Lett. 1992, 2, 1613. (b) Becker, D. P.; Nosal, R.; Zabrowski, D. L.; Flynn, D. L. Tetrahedron 1997, 53. (c) Becker, D. P.; Husa, R. K.; Moormann, A. E.; Villamil, C. I.; Flynn, D. L. Tetrahedron 1999, 55, 11787.

18. Becker, D. P.; Nosal, R.; Villamil, C. I.; Gullikson, G.; Moummi, C.; Yang, D.-C.; Flynn, D. L. Bioorganic \& Medicinal Chemistry Letters, 1997, 7, 2149-2154.

19. (a) Verhoeven, J. W.; Speckamp, W. N. Tetrahedron 1974, 30, 3525. (b) Dekkers, A. W. J. D.; Verhoeven, J. W.; Speckamp, W. N. Tetrahedron 1973, 29, 1691.

20. Kuznetsov, A. I.; Zefirov, N. S. Russ. Chem. Rev. 1989, 58, 1033.

21. (a) Becker, D. P.; Flynn, D. L.; Synthesis 1992, 1080. (b) Black, R. M. Synthesis 1981, 829.

22. Oldenziel, O.H.; van Leusen, D.; van Leusen, A. M. J. Org. Chem. 1977, 42, 3114.

23. Cumulative dose-response curves for agonists interacting with 5- $\mathrm{HT}_{4}$ receptors of rat TMM were done according to the method of Baxter, Craig and Clarke. See ref. 2.

24. Serotonin $5-\mathrm{HT}_{4}$ binding in guinea pig striatum was measured utilizing $\left[{ }^{3} \mathrm{H}\right]-\mathrm{GR} 113,808$ and was performed by MDS Pharma Services [formerly Panlabs Taiwan] according to the literature method: Grossman, C. J.; Kilpatrick, G. J.; Bunce, K. T. Br. J. Pharmacol. 1993, $109,618-624$.

25. The assay of Kilpatrick was employed for 5-HT 3 binding using $\left[{ }^{3} \mathrm{H}\right]-\mathrm{GR} 65630$ as the radioligand with male rat cortical tissue. See Kilpatrick, G. J.; Jones, B.J.; Tyers, M. B.; Nature, 1987, 330, 746.

26. The von Bezold-Jarisch Reflex assay was performed according to the literature: P. R. Saxena and A. Lawang, Arch. Int. Pharmacodyn. 1985, 277, 235.

27. Radioligands used for receptor profiling studies: $\left[{ }^{3} \mathrm{H}\right]-5-\mathrm{HT}$ for $5-\mathrm{HT}_{1}$-like receptors; $\left[{ }^{3} \mathrm{H}\right]$ ketanserin for $5-\mathrm{HT}_{2}$ receptors; [ $\left.{ }^{3} \mathrm{H}\right]-\mathrm{SCH} 23390$ for $\mathrm{D}-1$ receptors; [ $\left.{ }^{3} \mathrm{H}\right]$-spiperone for D-2 receptors; $\left[{ }^{3} \mathrm{H}\right]$-prazosin for alpha-1 adrenergic receptors.

28. (a) Jacoby, H.I. Brodie, D.A., Gastroenterology 1967, 52, 676-684. (b) Song, C. W.; Lee, K. Y.; Kim, C. D.; Chang T-M.; Chey, W. Y. J. Pharmacol. Exp. Ther. 1997, 281, 1312-1316.

29. Gullikson, G. W.; Virina, M. A.; Loeffler, R.; Erwin, W. D.; Am. J. Physiol. 1991a, 261, G426-432. 